\author{
EMILIA KUBICKA \\ Uniwersytet Mikołaja Kopernika w Toruniu \\ ekubicka@umk.pl \\ ORCID: 0000-0002-4026-5420
}

\title{
So-called dictionary equivalents confronted with parallel corpora (and the consequences for bilingual lexicography) ${ }^{*}$
}

\begin{abstract}
The study considers the question of whether (and how) bilingual dictionaries may be improved. The information presented in dictionaries has been confronted with textual reality (i.e., with examples of actual translations), based on the German expression fassungslos and its Polish equivalents in parallel texts. The author assumes that bilingual dictionaries are mainly used by language learners, while professional translators may consider them as one of many possible sources. In teaching, multiplying the possible equivalents or suggesting ad hoc solutions is generally not recommended. Despite the attempts at objectivizing lexicographic descriptions, which are made possible by using language corpora, it often turns out that the decisions made by dictionary authors are (and need to be) arbitrary.
\end{abstract}

KEYWORDS: Translation studies, bilingual lexicography, dictionary equivalents, parallel corpus.

\section{PRELIMINARY REMARKS}

Bilingual dictionaries are among the most popular and most commonly used types of dictionaries, particularly when it comes to learning foreign languages. At the early stages of the learning process, their content is rarely being questioned. This is also the case when they are used by non-specialists evaluating the quality of translations. However, scholars dealing with trans-

* The paper was written with the support of DAAD (The German Academic Exchange Service), within the framework of Re-invitation Program for Former Scholarship Holders (February-March 2018). 
lation studies have repeatedly pointed out to the gap between traditional bilingual dictionaries and actual textual reality, and called for the creation of translation dictionaries which reflect the actual linguistic equivalents used by translators. In the analysis that follows, the answers to the following questions are sought: Is the lexicographic image of the two linguistic systems compared so different from the translation reality that traditional dictionaries may be considered useless in the translation practice? Is it necessary and are we able to improve bilingual dictionaries?

Let us begin with confronting the lexicographic image of the German expression fassungslos and its Polish equivalents listed in dictionaries with the actual equivalents used in translated texts. The choice of the analyzed language expression is far from random. In German grammar studies, the status of fassungslos is unclear. Traditionally, it is considered an adjective (cf. Eisenberg 2006), because the class of adjectives in German includes expressions having adverbial and adjectival functions (cf. Telschow 2014). The semantic approach interprets it as a secondary predicate, referring to both agent / patient and to action (cf. Kubicka 2016). The ability of fassungslos to be involved in commenting on both the agent and the action in translation practice may be reflected on different levels of language. In the analysis that follows, there were took into consideration only those original texts where fassungslos has an adverbial function in the narrowest sense, i.e. comments on a verb.

\section{LEXICOGRAPHIC REALITY VS. TEXTUAL REALITY}

The lexicographic data analyzed in this paper has been excerpted from the three most comprehensive contemporary German-Polish dictionaries, i.e. the contemporary editions of the Wielki stownik niemiecko-polski [Great German-Polish dictionary] edited by Jan Piprek and Juliusz Ippoldt (WSNP Pipr / Ipp), created in 1957-1967; the popular dictionary edited by Andrzej Bzdęga, Jan Chodera and Stefan Kubica (PSNP) around the same period; and the newest PWN dictionary edited by Józef Wiktorowicz and Agnieszka Frączek (WSNP Wikt / Fr). Examples of actual textual uses come from a corpus of parallel texts (i.e., the originals and their translations) collected for the purposes of translation studies on adverbials ${ }^{1}$.

As far as the lexicographic image is concerned, fassungslos is presented in the following way:

\footnotetext{
${ }^{1}$ The collection of bitexts contains 30 original texts representing the idiolects of 16 authors from Germany, Austria and Switzerland and of 23 translators. The texts are mostly novels written between 1949 and 2015.
} 
WSNP Pipr/Ipp: adj adv zmieszany, wytrącony z równowagi; einer Sache gegenüberstehen być bezradnym wobec czegoś

PSNP: adj:adv przerażony, skonsternowany

WSNP Wikt/Fr: I przym st [spojrzenie, osoba] zdumiony; skonsternowany ksiażk; er war ganz był kompletnie wytrącony z równowagi II przyst. [stuchać, patrzeć] z zaskoczeniem, ze zdziwieniem

All three dictionaries note the formal homonymy of this expression, as isolated adjectives and adverbs have identical forms in German. However, only the most recent Polish dictionary provides adverbial equivalents of fassungslos (prepositional phrases $z$ zaskoczeniem, ze zdziwieniem). Using the standard notation found in older dictionaries ${ }^{2}$, the information they provide is to be understood as follows: the form fassungslos may have an adjectival or an adverbial function, yet its Polish equivalents are only adjectives / adjectival phrases, such as zmieszany, wytracony z równowagi (WSNP Pipr / Ipp) or przerażony, skonsternowany (PSNP). Note that the two dictionaries created during the same period suggest quite different equivalents of this expression. Taking into consideration the overall lexicographic image, we can see that fassungslos is rendered in Polish texts using adjectives / adjectival phrases such as zmieszany [embarrassed, confused], wytracony z równowagi [disturbed], bezradny [helpless], przerażony [terrified], skonsternowany [bewildered], zdumiony [astonished], or by adverbial expressions like prepositional phrases z zaskoczeniem and ze zdziwieniem [both meaning: to one's surprise]. Some of the adjectival equivalents refer to quite remote semantic meanings. All these expressions account for the different possible reactions to the events mentioned in the text. This variety of reactions stems from the fact that fassungslos can be described as a state of internal imbalance (usually caused by surprise), which manifests itself as the inability of the agent to say anything (cf. Duden Universalwörterbuch, LGWDaF).

The textual reality turns out to be even richer than the lexicographic image. The collected corpus contained 41 examples of fassungslos in Polish translations (eight authors, thirteen translators), and included the following equivalents:

adjectives/adjectival phrases: przerażony, skonsternowany, wytrącony z równowagi, zdumiony zmieszany [listed in the analyzed dictionaries] + ostupiaty [stunned], oszołomiony [shocked], skołowany [confused], zaskoczony [surprised], zaszokowany [shocked], zdezorientowany [disoriented]

adverbs: bezradnie [helplessly], tępo [dully]

2 Cf. e.g. the entry SCHNELL on WSNP Pipr / Ipp: “adj, adv szybk-i / o, prędk-i / o, pośpieszn-y / ie", providing both adjectival (szybki, etc.) and adverbial (szybko, etc.) equivalents. 
adverbial prepositional phrases: $w$ ostupieniu [literally: in astonishment], $w z a-$ kłopotaniu [lit. with embarrassment], $z$ niedowierzaniem [in disbelief], $z$ ostupieniem [lit. with astonishment]

quasi-Instrumentals: baranim wzrokiem [(to stare) gormlessly], nierozumiejacym wzrokiem [(to stare) without understanding], zaskoczonym wzrokiem [(to stare) with surprise], zdumionym wzrokiem [(to stare) in astonishment], petnymi zdumienia oczami [lit. (to stare) with eyes full of astonishment]

clauses, nominal clauses (cf. below, examples (2)-(3), (5)-(8) and (13)).

Note that none of these equivalents are likely to appear repeatedly in many contexts, which seems to confirm Roman Lewicki's (2017: 88) observation that

translated texts have a tendency to use occasional translatoric solutions, i.e. ad hoc equivalents of each of the uses of the expression which appears repeatedly in the original text. All these translatoric solutions turn out to be highly contextdependent, and independent from previously applied solutions ${ }^{3}$.

The translators' tendency to search for a new equivalent of an expression each time it is used in the text (cf. Lewicki 1986: 124-125) accounts for the fact that a translation is only one of the possible versions of the original. This becomes particularly clear if we compare different texts created by the same translator (in this case, Anna and Miłosz Urban, two translators working together on the Polish versions of Nele Neuhaus' books). The examples cited below have been grouped using semantic criteria: in fragments (1)-(4), fassungslos comments on the action of looking at something, (5)-(9) refer to speaking, (10)-(11) mention shaking one's head, while (12) describes the action of sighing and (13) - the process of realizing something.

(1) Sophia blickte ihn fassungslos an. (NN / LT / O: 93) $\rightarrow$ Sophia spojrzała na niego zaskoczona. (NN / LT / T: 100)

(2) Celina hielt noch immer den Geldschein in der Hand und blickte fassungslos auf ihre Kollegin, die plötzlich kein Gesicht mehr hatte. (NN / LT / O: 219) $\rightarrow$ Celina stała nieruchomo, wciąż jeszcze z wyciągniętą przez siebie dłonią z banknotem, i patrzyła, nie rozumiejąc, co się dzieje z jej koleżanką, której twarz nagle się zdematerializowała. (NN / LT / T: 236)

(3) Tobias starrte Bodenstein fassungslos an. (NN / SMS / O: 489) $\rightarrow$ Tobias wytrzeszczył oczy $i$ znieruchomiat. (NN / SMS / T: 474)

(4) Wie elektrisiert fuhren sie beide herum und starrten ihn fassungslos an. $(\mathrm{NN} / \mathrm{SMS} / \mathrm{O}:$ 510) $\rightarrow$ Oboje zatrzymali się jak rażeni piorunem. (NN / SMS / T: 494)

${ }^{3}$ Orig.: „"w przekładach występuje tendencja do okazjonalności rozwiązań translatorskich, tj. do doraźności tłumaczenia każdego użycia danego powtarzającego się w oryginale wyrażenia. Każde takie rozwiązanie translatorskie okazuje się w dużym stopniu zależne od swego kontekstu, a niezależnie od rozwiązań poprzednich". 
(5) „Erschossen? Meine Mutter wurde erschossen?“, flüsterte sie fassungslos. (NN / LT / O: 27) $\rightarrow$ - Zastrzelona?! Moja mama została zastrzelona?! wyszeptała kwiaciarka i jeszcze bardziej pobladta. (NN / LT / T: 30)

(6) „Nein...", flüsterte Christina Nowak fassungslos. (NN / TW / O: 385) $\rightarrow-$ Nie... - szepnęła Christina Nowak, kręcąc głową. (NN / TW / T: 382)

(7) [...] sagte Pia fassungslos. (NN / LT / O: 501) $\rightarrow$ [...] Pia potrząsnęła głowa, nie mogacc uwierzyć w to, co się stało. (NN / LT / T: 551)

(8) „Die ist ja total krank im Kopf”, sagte Pia fassungslos, als Nadja von Bredow von mehreren Polizisten abgeführt worden war. (NN / SMS / O: 458) $\rightarrow$ "Ależ ona ma nawalone we łbie!" - Pia pokręciła z niedowierzaniem głowa, kiedy kilku policjantów wyprowadziło Nadję von Bredow z sali przesłuchań. (NN / SMS / T: 445)

(9) „Frau Moormann!“, stieß sie fassungslos hervor. (NN/TW/O: 459) $\rightarrow$ - Pani Moormann! - sapnęła z niedowierzaniem. (NN/TW/T: 454)

(10) Las die Todesanzeige ein zweites Mal und schüttelte fassungslos den Kopf. Seine Hände zitterten. (NN / LT / O: 111) $\rightarrow$ Po raz kolejny przeczytał nekrolog i potrząsnął głową. Byt zdezorientowany i trzęsły mu się ręce. (NN / LT / T: 120)

(11) Sie schüttelte fassungslos den Kopf. (NN / LT / O: 304) $\rightarrow$ Przerażona potrząsała głową. (NN / LT / T: 334)

(12) Karoline schnappte fassungslos nach Luft. (NN / LT / O: 253) $\rightarrow$ Karoline aż sapnęła zaskoczona. (NN / LT / O: 276)

(13) Fassungslos begriff Nico, dass er soeben Zeuge eines Verbrechens geworden war. (NN / SMS / O: 54) $\rightarrow$ Powoli docierało do niego, że był świadkiem przestępstwa. (NN / SMS / T: 51)

The only expressions which appear repeatedly in the Urbans' translations are zaskoczona ((1) and (12)) and z niedowierzaniem ((9) and (8), where it is part of a larger expression). The feeling of surprise expressed in the original text with the use of fassungslos is rendered twice in translation with the image of shaking one's head ((6) and (8)). It is also clear that those particular translators have a tendency to translate this secondary predicate, using clauses or nominal clauses ((2)-(3), (5)-(8) and (13)). The examples cited above are yet another confirmation of the common truth, stating that translations, just like the originals, bear the mark of their creators' idiolect.

Comparing the lexicographic and the corpus image, we may easily notice that the first one is narrower than the other one. This problem will be discussed in the following sections of the paper, and it is not necessarily to be considered as a weakness of lexicographic descriptions. Moreover, note that the WSNP Wikt / Fr dictionary suggests $z$ zaskoczeniem and ze zdziwieniem as possible equivalents of fassungslos. Even though those expressions have not appeared in the small corpus, we may easily consider them as likely to be used, especially since the corpus equivalents include expressions referring to 
the state of zaskoczenie [surprise] and zdumienie [astonishment], which are close to $z$ dziwienie [amazement] ${ }^{4}$.

Confronting equivalents listed in the dictionaries with textual equivalents often leads researchers to conclude that there is a need for an improvement in bilingual dictionaries, which should be based on authentic texts and as a result should list actual translation equivalents. This seems to be a reasonable demand, which is, in fact, taken into consideration in contemporary monolingual lexicography using authentic examples gathered in language corpora. A (meta)lexicographer, however, could ask to what extent text usages are typical for a given language (or languages) and whether dictionaries should rather have a documentary function (which would be expected by researchers) or a normative ${ }^{5}$ (which is usually the users' expectation). In the case of bilingual dictionaries, the problem of the recipient seems to be crucial in answering any questions concerning the "authenticity" and comprehensive nature of equivalents listed. In others words, one should try to determine who are bilingual dictionary users and why they use these dictionaries.

\section{BILINGUAL DICTIONARIES IN THE EYES OF PUBLISHERS, METALEXICOGRAPHERS, LANGUAGE LEARNERS AND TRANSLATORS}

The difficulty in answering questions concerning the users of bilingual dictionaries results from the fact that dictionaries may be perceived differ-

${ }^{4}$ Let us note, however, that the publishers included the following statement in the dictionary Preface: "Both volumes have been prepared based on language corpora. Thanks to permanent access to those electronic sets of texts, lexicographers could select the most commonly used words and expressions in their natural form, not having to forge artificial examples" (orig.: "Obydwa tomy zostały przygotowane na podstawie korpusów językowych. Dzięki stałemu dostępowi do tych elektronicznych zbiorów tekstów leksykografowie mogli wyselekcjonować najczęściej występujące słowa i wyrażenia w naturalnej postaci, bez konieczności tworzenia sztucznych przykładów"). Such declarations seem exaggerated and potentially confusing for the readers, who are unlikely to know that the Polish-German/German-Polish parallel corpus has not been finished yet, which means that those authentic examples refer to each of the languages considered separately.

${ }^{5}$ In the case of general bilingual dictionaries, we could hardly speak of a normative function sensu stricto, as the lexicographer is not able to control the actual decisions of the translator. Steiner (1989: 252) talks about the prescriptive nature of bilingual dictionaries, arguing that the lexicographer, following the users' expectations, chooses and presents the "best" equivalents (which may not be referred to as "correct", since the meanings of expressions of two different languages are never identical). Piotrowski (1994: 26) considers bilingual dictionaries as predictive, stating that "a predictive dictionary is to provide such information on linguistic facts (description) that it would enable the user to behave linguistically like a native speaker (prediction). As to BDs [bilingual dictionaries], they should enable the user to behave either like a native speaker of either language (e.g. for production), or like competent bilingual (e.g. for translation)". 
ently by each of the professional groups dealing with lexicographic works: publishers (and lexicographers working for them), metalexicographers, language learners and translators.

The first ones advertise their dictionaries as suitable for everyone: language learners, translators, occasional users (tourists, etc.), as well as users wishing to read and write in a foreign language (cf. Piotrowski 1994: 35). Apart from a few exceptions, lexicographic practice does not reflect the division into passive and active dictionaries, postulated by metalexicographers following Lew Ščerba (cf. Kromann, Riiber \& Rosbach 1991), according to whom passive dictionaries should help understand foreign texts, while active ones should help create texts in a foreign language.

From the metalexicographic standpoint, bilingual dictionaries should serve communication, translation (Kromann 1989: 57; Kromann et al. 1991: 2725) and reading comprehension purposes (Piotrowski 1994: 35). Studies of bilingual dictionaries usually focus on two groups of users, i.e. language learners and translators (cf. e.g. Atkins 1998; Lew 2004).

Language learners tend to be reluctant in giving up on their bilingual dictionaries, even if their language skills are advanced enough to allow the use of a monolingual one. They do not wish to be provided with too much information and have a tendency to stop at the first listed equivalent, especially if it is separated from the following ones by a long list of examples. They are mostly interested in the meaning of linguistic expressions, rather than collocations, syntax or pronunciation (cf. Lew 2004: 17-33). The reluctance to use monolingual dictionaries, preferred and recommended by teachers, probably results from the lack of "immediate satisfaction" (Bogaards 2003: 27). Monolingual dictionaries are perceived as not providing direct access to language equivalents, explaining the unknown in an unknown language, using complicated expressions and / or grammar structures, providing excessive information and not referring to a specific pair of languages (por. Kromann 1989: 58; Wingate 2002: 23; Lew 2004: 4). However, they are also considered as very helpful for writing texts (cf. Lew 2004: 5-7).

In the process of language acquisition, bilingual dictionaries may have considerable advantages, presenting a specific pair of languages and offering equivalents which immediately help resolve linguistic problems (i.e. understand, or even create texts in a foreign language) without providing excessive information (cf. Kromann 1989: 58; Kromann, Riiber \& Rosbach 1991: 2725; Lew 2004: 8). Their weaknesses include not respecting the active / passive rule, which leads to a situation where certain information is missing, while other seems redundant; the lack of syntactic and stylistic information; and inadequate information on partial equivalents, i.e. on the differences between each of the equivalents listed, as well as between the 
equivalents and the original expression (cf. Kromann 1989: 60; Kautz 2000: 94; Wingate 2004: 24; Lew 2004: 9).

Thus, in the education process, bilingual dictionaries enable the students to comprehend, or even create texts. However, translations based on bilingual dictionaries differ considerably from professional translations. For language learners, dictionaries are usually ultimate sources of knowledge which are not questioned ${ }^{6}$ (cf. Gawron-Zaborska 2002). Meanwhile, in translation practice, bilingual dictionaries are simply one of the many resources that have to provide connotations necessary for finding a suitable equivalent for a given context (cf. Bornemann 1989; Piotrowski 1994; 2011). From the translators' point of view, a wide range of equivalents is definitely an advantage (cf. Bornemann 1989: 102; Snell-Hornby 1998: 182).

Let us recall that the translation process is not homogenous and consists of two phases: the receptive and the productive one (cf. Kautz 2000: 63-117). During the receptive phase, the translator analyses the original text, while the productive phase involves creating the translated version in the target language. A bilingual dictionary is obviously useful in the language comprehension phase, it may also be used during the production phase, as knowing the meaning and practical use of original expressions does not necessarily mean that the translator is always able to easily find their equivalents in the target language (cf. Farina 1996: 7). However, what distinguishes professional translations from "student" ones is the fact that professionals do not consider dictionary equivalents as final solutions, but rather as a starting point for finding the expressions which best suit each context (cf. Bornemann 1989: 99; Varantola 1998: 181; Piotrowski 1994: 30). This means that, during both the receptive and the productive phase, translators consider the equivalents offered by bilingual dictionaries as suggestions rather than canonic versions. This is due to the fact that they work with texts, and not with linguistic systems described in dictionaries, which means that they need much more than just lexical information and must take into consideration the syntactic and stylistic features of each expression ${ }^{8}$. Contrary to structuralists' visions (cf. e.g. Bogusławski 1976; 1978), a text is not

${ }^{6}$ In general, dictionary use is also absent from any discussion concerning didactic translation, cf. e.g. Lipińska and Seretny (2016), where the problem was not mentioned in the papers related to translation in language teaching.

${ }^{7}$ Certain authors consider that there are more than two phases, cf. e.g. Tarp's (2004: 30) three stages: "1) reception of source-language text, 2) transfer of text from source language into target language, 3) production of target-language text" (Hartmann 1995/2007 calls them, respectively, decoding, recoding and encoding). As we believe it is difficult to clearly distinguish the transfer phase from the production phase, we have decided to use Kautz's approach.

${ }^{8}$ For further analysis of the needs of translators, see Varantola (1998). 
merely a sum of lexical units which add up to produce the overall meaning. Hence, it is not enough to replace units of one language with units of another language which have been excerpted from "canonic translations" and listed in the dictionary9. While questioning the structuralist approach, Piotrowski is right to conclude that

a bilingual dictionary cannot in fact offer the user readily insertible equivalents to be used in translation because equivalents are text-specific, they are to a large degree unpredictable, or their number is too large to be included in a dictionary (Piotrowski 1994: 157).

This is why, in translation studies, bilingual dictionaries are considered as only one of many possible sources (cf. Snell-Hornby 1998; Kautz 2000; Pieńkos 2003). Alternatives include monolingual dictionaries, comparative and parallel corpora, encyclopedic sources, etc. Reinhard Hartmann (2004 / 2007: 46) portrays the translators' approach to dictionaries as a love-hate relationship, arguing that translation practice shows only too often that these basic tools cannot be trusted.

Thus, scholars often call for the creation of translation dictionaries (explicitly opposed to bilingual ones), which would be based on parallel corpora including equivalents used in authentic texts, and would describe the differences between each listed equivalent. They would also need to provide syntactic information, present each expression in the context and include not only linguistic, but also encyclopedic (cultural) information (cf. Snell-Hornby 1984; Steiner 1989; Henschelmann 1993; Snell-Hornby 1996; Rogers \& Ahmad 1998; Bralewski 2012).

\section{4. (META)LEXICOGRAPHIC IMPLICATIONS}

Generally, it could be said that bilingual dictionaries serve two groups of users: those wishing to comprehend texts and those wishing to create them. The understanding, and especially the creation process, take place in various conditions, which may include:

- an unprofessional context (e.g. in the case of tourists), where successful communication is a matter of communication skills and situational knowledge rather than pure language skills,

\footnotetext{
${ }^{9}$ Especially since translators do not follow lexicographic solutions (which is understandable, considering their arbitrary nature), just as lexicographers do not respect translators' decisions (which is difficult to understand, considering that dictionaries are supposed to reflect the actual language use and serve for creating texts which are acceptable and equivalent in the target language).
} 
- an educational context, where students need clearly described equivalents, allowing them to perceive the language system they try to master as more transparent, and

- a professional context, where the target text should not only be equivalent to the original, but also acceptable in the target culture.

Hence, it is impossible to create a dictionary suitable for all users, which is why Sue Atkins and Krista Varantola (1998: 83) suggest that "there are two direct routes to more effective dictionary use: the first is to radically improve the dictionary; the second is to radically improve the users". According to the authors, both of these solutions should be tried.

It seems clear that potential users should be taught how to make a wise use of their dictionaries and shown that these works should not be treated as ultimate solutions, but rather as reference points. It should be made clear to the users that bilingual dictionaries do not provide ready-made translations, because, just like monolingual ones, they are only an index of expressions belonging to a particular linguistic system (langue), which is often quite abstract and far from the textual parole (cf. Steiner 1989; Kautz 2002: 92-94). As we have shown above, professional translators have no difficulty in creating their own equivalents, regardless of the dictionary suggestions.

What can be done to make bilingual dictionaries more helpful? It is clear that they should provide authentic textual equivalents, which is now made possible thanks to the emerging comparative and parallel corpora. Considering the immense amount of corpus data, the actual question concerns rather the content and size of dictionary entries. The question is, how can we reconcile the needs of language learners, reluctant to read long lists of equivalents and large dictionary entries, with the needs of translators, who prefer to be provided with multiple equivalents and rich syntactic and pragmatic data?

It seems that, when creating bilingual dictionaries, lexicographers should concentrate on the needs of language learners. In language education, dictionaries are often the only tool used to help understand and create a text, while in the translation process, they are just one (and not the best) of the available tools. Nowadays, when it comes to translation practice, bilingual dictionaries tend to be replaced by parallel or comparative corpora ${ }^{10}$.

${ }^{10}$ Dictionaries of the future designed for translators are described as virtual databases, i.e. a combination of mono- and bilingual dictionaries and corpora, cf. Mackintosh (1998), Varantola (1998). One example of such "dictionary" derived automatically from the actual translations gathered in the Polish-English / English-Polish parallel texts is a list of equivalents generated in the Paralela corpus (paralela.clarin-pl.eu), cf. Pęzik (2016). 


\section{TEXTUAL REALITY CONFRONTED WITH DICTIONARY REALITY}

Let us come back to our example of fassungslos. What should be included in the dictionary entry referring to this expression? Assuming that it should not be too extensive or list any ad hoc (contextually bound) solutions, we could eliminate all clause and nominal clause equivalents. Even though translation is not bound to just one particular language level (which means that, for example, changing a grammar category in the target text is nothing unusual, cf. Bralewski 2012: 173-175; Lewicki 2017: 141-143), including such transformations in the dictionary (unless they are truly regular) would only make the linguistic image more blurry. Therefore, in the case of fassungslos, we should refrain from listing corpus equivalents in the form of quasiInstrumentals (such as zdumionym wzrokiem), unless we decide to include them in the example section, together with the appropriate verb which accompanies them in Polish. Thus, what is left are adjectives and adverbials in the form of adverbs and prepositional phrases.

The close relationship between adjectival and adverbial forms in German is a systemic feature which is of little relevance to Polish language users who tend to perceive the parts of speech appearing in foreign texts through the scope of their source language (in this case, Polish). This is why, inflectional information included in older dictionaries (adj adv in WSNP Pipr / Ipp and adj:adv in PSNP) seems to be more appropriate. Showing homonymous forms separately in WSNP Wikt/Fr is adequate while describing the language system, but, in this case, it turns out to be false. This solution suggests that adjectival uses of fassungslos are rendered in Polish using adjectives, while adverbial uses are translated with adverbials. In reality, the corpus examples discussed above include Polish equivalents of those German expressions which have only adverbial functions (i.e., comment on verbs) and yet, the equivalents represent both adverbial, adjectival and other-type structures. Strictly speaking, fassungslos is described in German grammar books as an adjective, and language units representing this part of speech may have both adjectival and adverbial functions (cf. Eisenberg 2006). Thus, the information provided in WSPN Wikt / Fr, according to which fassungslos is a homonymic form of adjective and adverb, applies to the target language (Polish), which equivalents were listed in two separate groups, but not to the source language (German). In this case the lexicographic coherence of a dictionary consistently presenting adjectival-adverbial forms as homonymous should give way to textual reality, that is much more complex. As for specific equivalents, we should supposedly list the most frequently used and the least stylistically marked ones (as being stylistically marked is a textual feature) - even though the problem of frequency turns out to be quite complex, 
given the fact that the most frequent equivalents appear only twice in our corpus, while the least frequent ones have appeared once. Considering that adverbs (classified as such according to Polish grammatical criteria, i.e. bezradnie and tępo in our corpus) are the least frequently used, they could be omitted. The dictionary entry would then include only adjectival forms and adverbial prepositional clauses. As frequency would no longer be the crucial factor, their choice would unfortunately become the lexicographer's arbitrary decision.

\section{CONCLUSIONS}

It is by no means innovative to conclude that lexicographic reality does not reflect textual reality (cf. comprehensive analyses by Bralewski 2012). Scholars have been criticizing traditional dictionaries and calling for a change for quite a long time. Attempting to answer the question of how to improve the existing dictionaries must start with defining the potential users of bilingual dictionaries (which should be distinguished from translation dictionaries). Assuming that they would mostly be used for educational purposes, we should not multiply possible equivalents, as an excess of information leads the readers to stop at the first listed equivalent(s). In theory, dictionaries should present the most frequently used expressions - however, in reality, decisions made by lexicographers would (have to) be arbitrary. A radical improvement of dictionaries, postulated by Atkins and Varantola (1998), would only be possible if accompanied by a radical improvement of dictionary users which, in turn, cannot happen without including lexicographic problems into language teaching process.

\section{REFERENCES}

Atkins, B. T. S. (ed.) (1998). Using dictionaries. Studies of dictionary use by language learners and translators. Lexicographica. Series Maior 88. Tübingen: Max Niemeyer.

Atkins, B. T. S. / Varantola, K. (1998). Monitoring dictionary use. In: B. T. S. Atkins (ed.), Using dictionaries. Studies of dictionary use by language learners and translators (pp. 83-122). Lexicographica. Series Maior 88. Tübingen: Max Niemeyer.

Bogaards, P. (2003). Uses and users of dictionaries. In: P. van Sterkenburg (ed.), A practical guide to lexicography (pp. 26-33). Amsterdam / Philadelphia: John Benjamins.

Bogusławski, A. (1976). Zagadnienie jednostek przekładowych. In: M. Bobran (ed.), Problemy jezzykoznawstwa porównawczego. Materiały lingwistycznej sesji naukowej w Rzeszowie 20-21 XI 1971 (pp. 41-62). Rzeszów: Wydawnictwo Uczelniane WSP.

Bogusławski, A. (1978) Uwagi o przekładzie i jego wartościowaniu. Przegląd Humanistyczny, 2, 39-52. 
Bornemann, E. (1989). Translation and lexicography: A practical view. In: B. Bennani / E. Pohl / M. Snell-Hornby (eds.), Translation and lexicography. Papers read at the EURALEX Colloquium held at Innsbruck 2-5 July 1987 (pp. 99-104). Amsterdam: John Benjamins.

Bralewski, D. (2012). Od przekładu do stownika. Korpus równoległy w redakcji słowników ttumaczeniowych. Rozumienie, Interpretacja, Przekład 9. Łask: Leksem.

Eisenberg, P. (2006). Grundriss der deutschen Grammatik. Vol. 2: Der Satz. Stuttgart: Metzler.

Farina, D. (1996). The bilingual lexicographer's best friends. Lexicographica. International Annual for Lexicography, 12, 1-15.

Gawron-Zaborska, M. (2002). „My ze słownikami nie dyskutujemy”, czyli o potrzebie rozwijania krytycyzmu studentów wobec słowników i innych źródeł. In: A. Kopczyński / U. Zaliwska-Okrutna (eds.), Jezzyk rodzimy a jezzyk obcy. Komunikacja, przekład, dydaktyka (pp. 191-197). Warszawa: Wydawnictwo Uniwersytetu Warszawskiego.

Hartmann, R. R. K. (1995/2007). Contrastive textology, bilingual lexicography and translation. In: R. R. K. Hartmann (ed.), Interlingual lexicography. Selected essays on translation equivalence, contrastive linguistics and the bilingual dictionary (pp. 38-45). Lexicographica. Series Maior 133. Tübingen: Max Niemeyer.

Hartmann, R. R. K. (2004/2007). Dictionaries for translators. In: R. R. K. Hartmann (ed.), Interlingual lexicography. Selected essays on translation equivalence, contrastive linguistics and the bilingual dictionary (pp. 46-52). Lexicographica. Series Maior 133. Tübingen: Max Niemeyer.

Henschelmann, K. (1993). Möglichkeiten und Grenzen von Übersetzungswörterbüchern am Beispiel französischer Abstrakta und ihres Entsprechungspotenzials im Deutschen. In: G. Rovere / G. Wotjak (eds.), Studien zum romanisch-deutschen Sprachvergleich (pp. 19-39). Linguistische Arbeiten 297. Tübingen: De Gruyter.

Kautz, U. (2000). Handbuch Didaktik des Übersetzens und Dolmetschens. München: Goethe Institut.

Kromann, H.-P. (1989). Neue Orientierung der zweisprachigen Wörterbücher. Zur funktionalen zweisprachigen Lexikographie. In: B. Bennani / E. Pohl / M. Snell-Hornby (eds.), Translation and lexicography. Papers read at the EURALEX Colloquium held at Innsbruck 2-5 July 1987 (pp. 55-65). Amsterdam: John Benjamins.

Kromann, H.-P. / Riiber, Th. / Rosbach, P. (1991). Principles of bilingual lexicography. In: F. J. Hausmann / O. Reichmann / H. E. Wiegand / L. Zgusta (eds.), Wörterbücher. Dictionaries. Dictionnaires. Ein internationales Handbuch zur Lexikographie. Vol. 3 (pp. 2711-2728). Handbücher zur Sprach- und Kommunikationswissenschaft 5.3. Berlin / New York: Walter de Gruyter.

Kubicka, E. (2016). Deutsche sekundäre Prädikate in polnischen Übersetzungen. In: E. Gutiérrez Rubio / E. Kislova / E. Kubicka (eds.), Beiträge der Europäischen Slavistischen Linguistik (POLYSLAV). Bd. 19 (pp. 155-164). Die Welt der Slaven 60. Wiesbaden: Harrasowitz.

Lew, R. (2004). Which dictionary for whom? Receptive use of bilingual, monolingual and semibilingual dictionaries by Polish learners of English. Poznań: Motivex.

Lewicki, R. (2017). Zagadnienia lingwistyki przekładu. Lublin: Wydawnictwo UMCS.

Lipińska, E. / Seretny, A. (eds.) (2016). Tłumaczenie dydaktyczne w nowoczesnym kształceniu językowym. Biblioteka LingVariów. Glottodydaktyka 12. Kraków: Księgarnia Akademicka.

Mackintosh, K. (1998). An empirical study of dictionary use in L2-L1 translation. In: B. T. S. Atkins (ed.), Using dictionaries. Studies of dictionary use by language learners and translators (pp. 123-149). Lexicographica. Series Maior 88. Tübingen: Max Niemeyer.

Pęzik, P. (2016). Exploring phraseological equivalence with paralela. In: E. Gruszczyńska / A. Leńko-Szymańska (eds.), Polish-language parallel corpora (pp. 67-81). Warszawa: Instytut Lingwistyki Stosowanej UW.

Pieńkos, J. (2003). Podstawy przekładoznawstwa. Od teorii do praktyki. Katowice: Zakamycze. 
Piotrowski, T. (1994). Problems in bilingual lexicography. Wrocław: Wydawnictwo Uniwersytetu Wrocławskiego.

Piotrowski, T. (2011). Ekwiwalencja w słownikach dwujęzycznych. In: W. Chlebda (ed.), Na tropach translatów. W poszukiwaniu odpowiedników przekładowych (pp. 45-69). Opole: Wydawnictwo Uniwersytetu Opolskiego.

Rogers, M. / Ahmad, K. (1998). The translator and the dictionary: Beyond words? In: B. T. S. Atkins (ed.), Using dictionaries. Studies of dictionary use by language learners and translators (pp. 193-204). Lexicographica. Series Maior 88. Tübingen: Max Niemeyer.

Snell-Hornby, M. (1984). The bilingual dictionary - help or hindrance? In: R. R. K. Hartmann (ed.), LEXeter' 83 proceedings. Papers from the International Conference on Lexicography at Exeter, 9-12 September 1983 (pp. 274-281). Lexicographica. Series Maior 1. Tübingen: Max Niemeyer.

Snell-Hornby, M. (1996). The translator's dictionary - An academic dream? In: M. Kadric / K. Kaindl (eds.), Translation und Text. Ausgewählte Vorträge (pp. 90-96). Wien: Wiener Universitätverlag.

Snell-Hornby, M. (1998). Wörterbücher. In: M. Snell-Hornby / H. G. Hönig / P. Kußmaul / P. A. Schmitt (eds.), Handbuch Translation (pp. 181-184). Tübingen: Stauffenburg.

Steiner, R. J. (1989). The absence of text: The bilingual dictionary as an index. International Journal of Lexicography, 2 (3), 249-257.

Tarp, S. (2004). How can dictionaries assist translators? In: Ch. Sin-wai (ed.), Translation and bilingual dictionaries (pp. 23-38). Lexicograhpica. Series Maior 119. Tübingen: Max Niemeyer.

Telschow, C. (2014). Die Adjektiv-Adverb-Abgrenzung im Deutschen. Zu grundlegenden Problemen der Wortartenforschung. Reihe Germanistische Linguistik 299. Berlin / Boston: Walter de Gruyter.

Varantola, K. (1998). Translators and their use of dictionaries: User needs and user habits. In: B. T. S. Atkins (ed.), Using dictionaries. Studies of dictionary use by language learners and translators (pp. 179-192). Lexicographica. Series Maior 88. Tübingen: Max Niemeyer.

Wingate, U. (2002). The effectiveness of different learner dictionaries. An investigation into the use of dictionaries for reading comprehension by intermediate learners of German. Lexicographica. Series Maior 112. Tübingen: Max Niemeyer.

\section{DICTIONARIES}

Duden: Duden Universalwörterbuch. o.D. $6^{\text {th }}$ edition. Mannheim: Duden.

LGWWDaF: Götz, D. / Haensch, G. / Wellmann, H. (eds.). (2003). Langenscheidt Großwörterbuch Deutsch als Fremdsprache. Berlin: Langenscheidt.

PSNP: Bzdęga, A. / Chodera, J. / Kubica, S. (eds.). (1966/1992). Podręczny stownik niemiecko-polski. Handwörterbuch Deutsch-Polnisch. 11 $1^{\text {th }}$ edition. Warszawa: Wiedza Powszechna.

WSNP Pipr / Ipp: Piprek, J. / Ippoldt, J. et al. (eds.). (1969-1974/2002). Wielki stownik niemiecko-polski. Großwörterbuch Deutsch-Polnisch. 13 $3^{\text {th }}$ edition. Warszawa: Wiedza Powszechna.

WSNP Wikt / Fr: Wiktorowicz, J. / Frączek, A. (eds.). (2008). Wielki stownik niemiecko-polski PWN. Großwörterbuch Deutsch-Polnisch, Warszawa: Wydawnictwo Naukowe PWN

\section{SOURCES OF EXAMPLES CITED}

NN / LT / O: Neuhaus, N. (2014/2015). Die Lebenden und die Toten. $2^{\text {nd }}$ edition. Berlin: Ullstein. NN / LT / T: Neuhaus, N. (2015). Żywi i umarli. Transl. by A. Urban \& M. Urban. Poznań: Media Rodzina.

NN / SMS / O: Neuhaus, N. (2010/2015). Schneewittchen muss sterben. 32nd edition. Berlin: List. 
NN / SMS / T: Neuhaus, N. (2013). Śnieżka musi umrzeć. Transl. by A. Urban \& M. Urban. Poznań: Media Rodzina.

NN / TW / O: Neuhaus, N. (2009/2015). Tiefe Wunden. 30th edition. Berlin: List.

NN / TW / T: Neuhaus, N. (2013). Głębokie rany. Transl. by A. Urban \& M. Urban. Poznań: Media Rodzina.

Received: 3.12.2018; revised: 18.10 .2019 